\title{
Application of Visual
} Project Management to build a pro-sustainability \section{design tool}

Valdecir Babinski Júnior

Master, Universidade do Estado de Santa Catarina / vj.babinski@gmail.com Orcid: 0000-0002-5298-4756 / lattes

\section{Lucas da Rosa}

PhD, Universidade do Estado de Santa Catarina / darosa.lucas@gmail.com Orcid: 0000-0002-8429-2754 / lattes

\section{Dulce Maria Holanda Maciel}

PhD, Universidade do Estado de Santa Catarina / dulceholanda@gmail.com Orcid: 0000-0002-0602-0198 / lattes

\section{Icléia Silveira}

PhD, Universidade do Estado de Santa Catarina / icleiasilveira@gmail.com Orcid: 0000-0003-4493-9768/ lattes

Sent: 07/29/2020 // Accepted: 12/12/2020 


\title{
Application of Visual Project Management to build a pro- sustainability design tool
}

\begin{abstract}
The article aims to present the application of Visual Project Management in the construction of a pro-sustainability project tool with an emphasis on the mitigation of solid textile waste. This is the Zero Waste Tool for Apparel Design (ZWTAD). The construction of the tool took place in two stages: (I) initially, based on the use of the visual panel of the Orientation Guide for Project Development; and (II), then, under the application of the structural elements (premises, requirements and usability principles) of Visual Project Management. Therefore, methodologically, this article can be understood as applied, descriptive, bibliographic and qualitative research. It is inferred that the development of the ZWTAD can constitute a case of Visual Project Management, however, for now, it is still an incomplete visual model.
\end{abstract}

Keywords: Visual Project Management. Design tools. Zero Waste Design. 


\title{
Aplicação da Gestão Visual de Projetos para a construção de uma ferramenta projetual pró- sustentabilidade
}

\begin{abstract}
RESUMO
O artigo tem como objetivo apresentar a aplicação da Gestão Visual de Projetos na construção de uma ferramenta projetual pró-sustentabilidade com ênfase na mitigação de resíduos sólidos têxteis. Trata-se da ferramenta projetual Zero Waste Tool for Apparel Design (ZWTAD). A construção da ferramenta ocorreu em duas etapas: (I) inicialmente, calcada no uso do painel visual do Guia de Orientação para Desenvolvimento de Projetos; e (II), em seguida, sob aplicação dos elementos estruturantes (premissas, requisitos e princípios de usabilidade) da Gestão Visual de Projetos. Portanto, metodologicamente, este artigo pode ser compreendido como pesquisa aplicada, descritiva, bibliográfica e qualitativa. Infere-se que o desenvolvimento da ferramenta ZWTAD pode se constituir em um case da Gestão Visual de Projetos, contudo, por hora, essa ainda se encontra como modelo visual incompleto.
\end{abstract}

Palavras-chave: Gestão Visual de Projetos. Ferramentas projetuais. Zero Waste Design. 


\title{
Aplicación de la Gestión de proyectos visuales para construir una herramienta de diseño pro- sostenibilidad
}

\begin{abstract}
RESUMEN
El artículo tiene como objetivo presentar la aplicación de la Gestión de proyectos visuales en la construcción de una herramienta de proyecto pro-sostenibilidad con énfasis en la mitigación de residuos sólidos textiles. Esta es la herramienta de diseño Zero Waste Tool for Apparel Design (ZWTAD). La construcción de la misma se llevó a cabo en dos etapas: (I) inicialmente, basada en el uso del panel visual de la Guía de Orientación para el Desarrollo de Proyectos; y (II), entonces, bajo la aplicación de los elementos estructurales (premisas, requisitos y principios de usabilidad) de la Gestión de proyectos visuales. Por lo tanto, metodológicamente, este artículo puede entenderse como investigación aplicada, descriptiva, bibliográfica y cualitativa. Se infiere que el desarrollo de la herramienta ZWTAD puede constituir un caso de la Gestión de proyectos visuales, sin embargo, por ahora, todavía es un modelo visual incompleto.
\end{abstract}

Palabras clave: Gestión visual de proyectos. Herramientas de diseño. Zero Waste Design. 


\section{INTRODUCTION}

The zero waste approach to Apparel Design has the goal to mitigate solid textile waste in productive processes that involve creation, patternmaking, and production of a clothing collection (RISSANEN, 2013; BINOTTO; PAYNE, 2016; RIZZI, 2018). According to Firmo (2014) and Breve (2018), in traditional processes, this waste represents $15 \%$ to $20 \%$ of the raw material used. Which implies, for example, that for each 100 meters of woven fabric used by the clothing industry, approximately 20 meters can be discarded even before becoming part of a product.

Because of this problem, pro-sustainability design tools that intend to subsidize project teams in decision making regarding the materialization of clothing collections are emerging. As an example, we bring the Zero Waste Tool for Apparel Design (ZWTAD), this article's research object. The tool originated in Valdecir Babinski Júnior's master's research, named Design tool for a zero waste approach in Apparel Design. The thesis was along the Apparel Design and Technology research line, from the Programa de Pósgraduação em Design de Vestuário e Moda (PPGModa), from the Centro de Artes (Ceart) of the Universidade do Estado de Santa Catarina (Udesc) and was advised by Professor Lucas da Rosa.

Stemming from the research object, this article aims at presenting how the application of Visual Project Management occurred in the construction of the ZWTAD. For this purpose, the article follows the deductive scientific method logic, which, to Gil (2008, p. 9, our translation), "[...] stems from principles taken as true and indisputable and makes it possible to reach conclusions in a purely formal way $[\ldots]^{\prime \prime}$. Its nature is purely 
based on its own operational logic, which allows to classify this article as a descriptive research.

As for the technical procedures used in this article, a nonsystematic bibliographic survey was used, based on authors chosen by their association with the central theme, Visual Project Management, and with the intention to report their application to the ZWTAD. It is important to highlight that there were no inclusion or exclusion criteria for the survey, and that the authors were chosen using the snowball sampling technique. Gil (2008) states that the advantage of using bibliographic research is the possibility of investigating multiple realities (secondary data), beyond the immediate researchable phenomena (primary data).

After the bibliographic survey and the organization of the article's body of knowledge, which followed the narrative literature research format, a qualitative analysis was used as a technical procedure to make sense of the academic findings, which were treated through an interpretive epistemological stance. Regarding qualitative research, Gil (2008) believes that statistical data become dispensable and, in counterpoint, what should be interpreted is the phenomenon observed under the optics of those who are investigating it.

This article also tends toward design science research, because it is close to the artifact construction heuristics. As established by Dresch, Lacerda, and Antunes Júnior (2015), the design science research method is about satisfactory solving specific problems which are rooted in artifact prescription or design. These artifacts can have the format of a construct, a model, a method, a design proposition, or, in the case of this article, a tool.

Dresch, Lacerda, and Miguel (2015, p. 1118, our translation) observe that the design science research method allows "[...] the researcher not only to explore, describe, or 
explain a certain phenomenon, but also to design or prescribe solutions to a given problem". The authors also clarify that:

[...] design science research has been presented as a research method that gives attention to the development of studies that aim at prescribing, designing, and, also, constructing artifacts. This research method has design science as an epistemological basis, a concept that differs from traditional sciences for dealing with the artificial, that is, everything that was designed and conceived by man (DRESCH; LACERDA; MIGUEL, 2015, p. 1124, our translation).

Dresch, Lacerda, and Miguel (2015) point as essential elements of the method in question: (I) problem; (II) solution; (III) development; (IV) evaluation; (V) adding value; and (VI) communication. Based on these elements, Dresch, Lacerda, and Antunes Júnior (2015) present as steps for a design science research: (I) identification of the problem; (II) problem awareness; (III) systematic literature review; (IV) artifact identification and proposition of problem classes; (V) artifact proposition aiming at solving an specific problem; (VI) artifact design; (VII) artifact development; (VIII) artifact evaluation; (IX) record of learning; (X) conclusions; (XI) formulation of generalizations for a class of specific problems; and (XII) communication of results.

Dresch, Lacerda, and Antunes Júnior (2015) add that, while following the aforementioned steps, the researcher takes the role of designer and evaluator of the artifact. To achieve our goal, we adopted this view, however, some of the design science research steps were suppressed, such as the systematic literature review and the formulation of generalizations for classes of problem. This happened because of the partial inadequacy of the research purpose to the design science research scientific rigor. 
Thus, through Gil (2008), this article can be understood as applied research, regarding its purpose; as descriptive research, regarding the technical procedure used; and, at last, as qualitative research, regarding the approach to the investigated object.

\section{ZERO WASTE TOOL FOR APPAREL DESIGN}

Understood as the material expression produced by the Fashion sociocultural phenomenon, Apparel Design entails industrial serialization of products organized based on a specific clothing collection. For each collection there is planning, which summarily contains three distinct and consecutive macro steps: (I) creation; (II) patternmaking; and (III) sewing (TREPTOW, 2007; ROSA, 2011; BONA, 2019).

Design tools can be applied at each macro step of the collection planning. For Bona (2019, p. 27, our translation), such tools can be seen as physical, visual, schematics, or conceptual instruments "[...] in charge of helping with information inputs in order to obtain outputs". The author mentions that design tools help incite methodological reasoning regarding collection planning and that, consequently, it can "provoke connections for directing the design thinking in different stages of the project and according to the problem that needs to be solved" (BONA, 2019, p. 60, our translation).

The ZWTAD is an example of a design tool that can be used to plan a clothing collection. It was developed to ensure that there is no material or solid textile waste in the clothing productive process. The ZWTAD was elaborated in two steps, which can be described as before and after application of 
Visual Project Management. The description of these steps is in the following topics of this article.

\subsection{ZWTAD before the application of Visual Project Management}

In the first construction step, the ZWTAD was drafted using the Guidance of Development Projects (GDP) visual panel, created by Merino (2014; 2016). According to Merino, Varnier, and Makara (2020, p. 18-19, our translation), the main goal of the GDP panel is:

[...] to organize and offer a sequence of actions that enables Design to be planned consciously, considering as many aspects as possible, in order to meet the goals of the project. Besides, it is flexible and adaptable, which allows adjustments throughout the process, according to each project's particularities [...].

Merino, Varnier, and Makara (2020) say that the guide has

8 steps: (I) opportunities; (II) prospection/solicitation; (III) data survey; (IV) organization and analysis of data; (V) creation; (VI) execution; (VII) viabilization; and (VIII) verification. According to the authors, the GDP steps can be comprehended in three moments: (I) inspiration, which encompasses the first, second, and third steps; (II) ideation, which is related to the fourth and fifth steps; and (III) implementation, which contains the sixth, seventh, and eighth steps (Figure 1). 
Figure 1. Moments and steps of the GDP

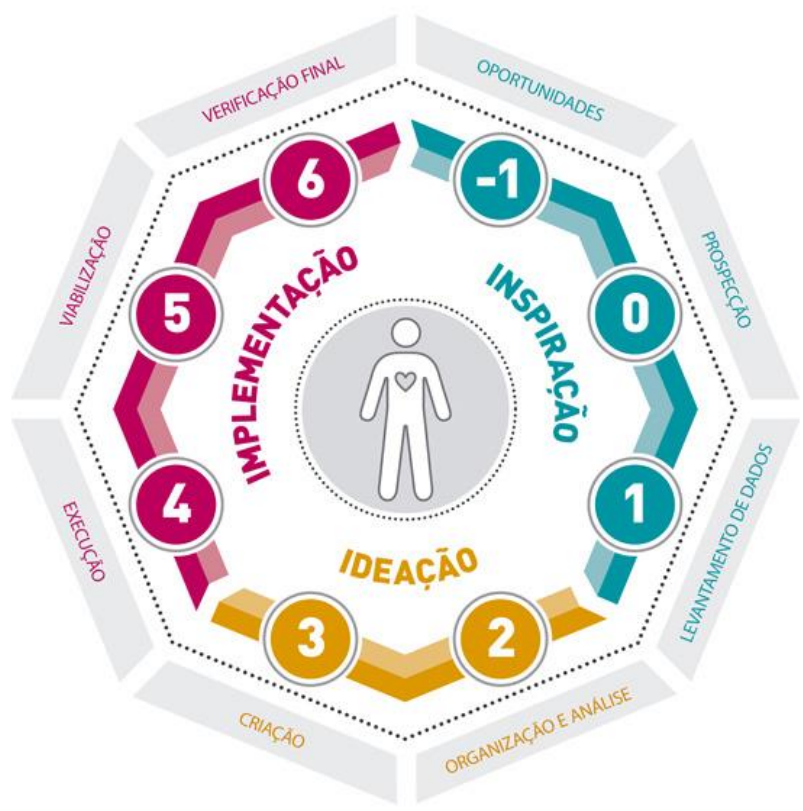

Source: Merino (2016, p. 15).

For each step on the visual panel (Figure 1), GDP stipulates goals that articulate the product ("what is the product?"), the users ("who are/will be the users?"), and the context ("where will the product be inserted?"). Thus, to Merino (2014; 2016), in the first step the market opportunities must be verified, in local, national, and international levels, with emphasis in the need for growth of the sector in which you want to work in.

In the second step, the goal is to define demands that can compose the project's central problem. In the third step, through data survey, the project is specified and adapted according to expectations of its future users and to current technical standards, in accordance with the nature of the developing product (MERINO, 2014; 2016).

In the fourth step, the surveyed data is organized, analyzed, and aligned with the project's strategies. In the fifth step, the global concepts of the project are defined, and the first prototypes are created. In the sixth step, the approved 
prototypes are modelled in real scale and a life cycle is stipulated for the product (MERINO, 2014; 2016).

In the seventh step, Merino $(2014 ; 2016)$ anticipates that the prototype that best meets the project's specifications will be chosen. At this point, the product must be tested alongside potential buyers through tools that evaluate ergonomics, apparent quality, usability, comfort, or other requirements deemed pertinent to the product. At last, in the eighth step, the systemic thinking must be favored, and the environmental, economic, and social impacts of the product must be taken into account. Figure 2 presents the application of the GDP's visual panel in the ZWTAD context.

Figure 2. Photographic records of the construction of the ZWTAD, based on GPD

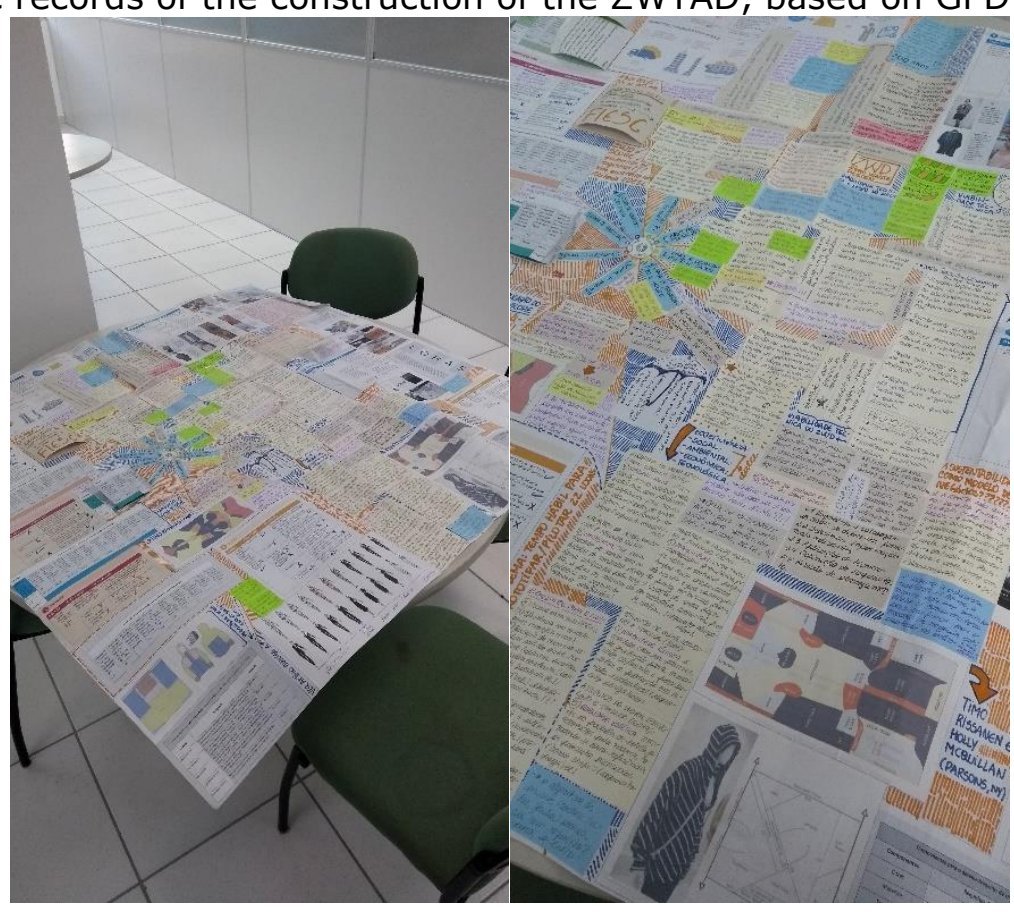

Source: elaborated by the authors (2021).

The visual complexity of the results (Figure 2) was summarized via a list of project requirements and presented as a table of steps, as proposed by Merino $(2014 ; 2016)$ in the perspective of the fourth GDP stage. To organize and 
simplify the use of the tool, a score for each requirement was established based on the Likert Scale, with the purpose of listing project requirements for the three macro steps (creation, patternmaking, and sewing) of the clothing collection planning. It is important to clarify that the Likert Scale was designed to measure individuals' attitudes and behaviors (GIL, 2008).

Before presenting the table of steps, however, it is necessary to highlight the contribution of Vieira, Iervolino, and Stadler (2019). The authors created a checklist with mandatory and desirable attributes in the context of a zero waste legging project. Namely: (I) raw material; (II) anthropometry; (III) patternmaking; (IV) technical viability; and $(\mathrm{V})$ aesthetic quality (Table 1 ).

Table 1. List of requirements for a zero waste legging project

\begin{tabular}{|l|l|l|}
\hline Attribute & Designation & Priority \\
\hline Raw material & $\begin{array}{l}\text { Use of ecological and } \\
\text { certified fabrics. Verification } \\
\text { of which fabrics are already } \\
\text { used by the brand and if } \\
\text { they have enough comfort } \\
\text { and elasticity to fulfill the } \\
\text { movement needs of the } \\
\text { users' bodies. }\end{array}$ & \\
\hline Anthropometry & $\begin{array}{l}\text { Creation of models } \\
\text { according tory to the } \\
\text { measurements of industrial } \\
\text { tables already used by the } \\
\text { brand. Attention to the } \\
\text { fulfillment of the ergonomic } \\
\text { and anthropometric needs of } \\
\text { the users. }\end{array}$ & \\
\hline Patternmaking \\
$\begin{array}{ll}\text { Creation of a geometric } \\
\text { pattern focused on the } \\
\text { perfect fit, to avoid waste of } \\
\text { material and to include the } \\
\text { minimum parts of the } \\
\text { patterns, such as pockets, } \\
\text { waistbands, applications, } \\
\text { collars, etc. }\end{array}$ & \\
\hline
\end{tabular}




\begin{tabular}{|l|l|l|}
\hline $\begin{array}{l}\text { Technical } \\
\text { viability }\end{array}$ & $\begin{array}{l}\text { The created models must be } \\
\text { adaptable to different sizes, } \\
\text { according to the brand's } \\
\text { wishes, and they also need } \\
\text { to allow serial production of } \\
\text { the product (industrial } \\
\text { scale). }\end{array}$ & Mandatory \\
\hline $\begin{array}{l}\text { Aesthetic } \\
\text { quality }\end{array}$ & $\begin{array}{l}\text { Maintenance of the aesthetic } \\
\text { already embraced by the } \\
\text { brand in its collections } \\
\text { (visual identity of the brand } \\
\text { in the market in which it } \\
\text { operates). }\end{array}$ & \\
\hline
\end{tabular}

Source: adapted from Vieira, Iervolino, and Stadler (2019, p. 519-520).

Stemming from Table 1, which was obtained via the third GDP step (data survey), the attributes listed by Vieira, Iervolino, and Stadler (2019) were transformed into ten project requirements that, in turn, were classified using the creation, patternmaking, and sewing macro steps. The requirements classified as mandatory got a score between 20 points (minimum) and 30 points (maximum). The desirable requirements got a score between 5 points (minimum) and 15 points (maximum). In an ideal scenario, the score obtained by a user who employs all the requirements reaches 130 points (Table 2).

Table 2. The ZWTAD before the application of Visual Project Management

\begin{tabular}{|l|l|l|}
\hline Macro step & Project requirement & Score \\
\hline Creation & $\begin{array}{l}\text { 1. Aesthetic quality, } \\
\text { adaptation and continuation } \\
\text { of previously developed } \\
\text { work, and attention to } \\
\text { trends. }\end{array}$ & \\
\cline { 2 - 3 } & $\begin{array}{l}\text { 2. Coordination with other } \\
\text { pro-sustainability strategies. }\end{array}$ & +5 \\
\cline { 2 - 3 } & $\begin{array}{l}\text { 3. Choice of ecological and } \\
\text { certified raw material or non- } \\
\text { virgin raw material. }\end{array}$ & +10 \\
\hline
\end{tabular}




\begin{tabular}{|c|c|c|}
\hline \multirow[t]{4}{*}{ Patternmaking } & $\begin{array}{l}\text { 4. Geometric pattern designs } \\
\text { that prioritize the patterns' } \\
\text { perfect fit. }\end{array}$ & +25 \\
\hline & $\begin{array}{l}\text { 5. Use of eco-efficiency in } \\
\text { pattern fitting } \\
\text { (patternmaking } \\
\text { optimization). }\end{array}$ & +30 \\
\hline & $\begin{array}{l}\text { 6. Anthropometric aspects } \\
\text { and use of measurements } \\
\text { according to the industrial } \\
\text { tables, with the current } \\
\text { standards for the segment } \\
\text { and with the prospected } \\
\text { users' biotypes. }\end{array}$ & +5 \\
\hline & $\begin{array}{l}\text { 7. Scalability and technical } \\
\text { viability to allow serial } \\
\text { production of the product(s) } \\
\text { (adaptation of pattern sizes). }\end{array}$ & +20 \\
\hline \multirow[t]{3}{*}{ Sewing } & $\begin{array}{l}\text { 8. Operational sequence with } \\
\text { a minimum of possible } \\
\text { operations in the assembling } \\
\text { of clothes (preparation and } \\
\text { sewing). }\end{array}$ & +5 \\
\hline & $\begin{array}{l}\text { 9. Mitigation of waste in } \\
\text { secondary } \\
\text { processes } \\
\text { patternmaking, (prototyping, } \\
\text { etc.). }\end{array}$ & +15 \\
\hline & $\begin{array}{l}\text { 10. Production of only } \\
\text { inevitable minimum waste } \\
\text { (trimmings, spare threads, } \\
\text { selvages). }\end{array}$ & +10 \\
\hline
\end{tabular}

Source: elaborated by the authors (2021).

After creating Table 2, to calculate the maximum score to be obtained, it was stipulated that: (I) maximum score will be given if the design tool user totally fulfills the requirements; and (II) zero points will be given if the design tool user does not fulfill or partially fulfills the requirements.

In accordance with the seventh GDP step, we sought to test the ZWTAD with models found in Apparel Design zero waste literature. For this purpose, five random examples were chosen: (I) Madeleine Vionnet; (II) Contextura; (III) Timo 
Rissanen; (IV) Zandra Rhodes; and (V) Vieira, Iervolino, and Stadler (2019).

Madeleine Vionnet, the first example, was a French stylist working at the beginning of Haute Couture, in the 20th century. Born in 1876 and deceased in 1975, Vionnet influenced the work of several contemporary professionals through her studies on fabric fitting. Regarding zero waste, Vionnet developed pieces that used $100 \%$ of the material through bias cut and moulage technique (three-dimensional patternmaking) (RISSANEN, 2013; FIRMO, 2014; BINOTTO; PAYNE, 2016; BREVE, 2018; RIZZI, 2018). When the ZWTAD was applied, the example fulfilled four of the requirements ( 1 , 5,8 , and 10) and got 50 points.

The second example found in the literature and chosen for the tool test was Contextura, a brand from Rio Grande do Sul, Brazil. Founded in 2010 by the professors Anne Anicet and Evelise Anicet as a textile research lab, Contextura has been developing since then works that congregate art, technology, fashion, design, and sustainable development. Its main productive processes involve sublimation printing, moulage, and textile collages, which, in its turn, use waste from previous processes as raw material (ANICET; RÜTHSCHILLING, 2013; FIRMO, 2014; RIZZI, 2018). When the example was submitted to the ZWTAD, eight of the requirements were fulfilled $(1,2,3,4,6,8,9$, and 10), achieving 80 points.

The third example regards the work of the designer and professor at the North American Parsons The New School of Art and Design, Timo Rissanen. Jha and Narang (2015, p. 6) mention Rissanen's technique as a "[...] 'jigsaw-puzzle approach' to design and patternmaking $[\ldots]^{\prime \prime}$. In his technique, Rissanen seeks the full use of fabric through organic patterns and curvilinear strokes that fit perfectly in 
the two-dimensional plane. This makes the operational sequence more complex to execute than other techniques (RISSANEN, 2013; FIRMO, 2014; BREVE, 2018; RIZZI; 2018). Regarding the ZWTAD, the example fulfilled eight of the requirements $(1,2,3,5,6,7,9$, and 10), achieving 80 points.

The fourth example is the work of English stylist Zandra Rhodes. Born in 1940, the stylist was cited by Rissanen (2013), Firmo (2014), and Breve (2018) as a pioneer and a contemporary example in the application of zero waste principles in clothing patternmaking. According to Firmo (2014), the stylist's work is recognized by the international community since the 1970s, when her predominant use of organic materials and of her embroideries, knitting, and crochets defined her style. For the author, currently, Rhodes' style is characterized by the creation of different prints, which are used as much as possible in her collections, and the rigorous geometric shape of her patterns which constantly mix squares and rectangles to obtain an $100 \%$ fit. In the ZWTAD application, this example fulfilled nine requirements $(1,2,3$, $4,5,6,8,9$, and 10) and got 110 points.

The fifth and last example used to test the design tool in question came from the zero waste experience mentioned by Vieira, Iervolino, and Stadler (2019). When developing their industrially scalable leggings design, Vieira, Iervolino, and Stadler (2019) concluded that zero waste patternmaking efficiency can be reached if: (I) geometric designs are used in the patterns' layout, preferably with $90^{\circ}$ angles; (II) the width of the pattern's parts is multiple of the fabric's width; (III) the different sizes allow the patterns to repeat themselves on the fabric with multiple fitting possibilities. Thus, when the example was applied to the ZWTAD, all the requirements were 
fulfilled, and it got the maximum score of 130 points (Table 3).

Table 3. Testing of the ZWTAD based on five examples from the literature

\begin{tabular}{|l|l|l|l|l|l|l|}
\hline $\begin{array}{l}\text { Project } \\
\text { requirement }\end{array}$ & $\begin{array}{l}\text { Scor } \\
\mathbf{e}\end{array}$ & $\begin{array}{l}\text { Example } \\
\mathbf{1}\end{array}$ & $\begin{array}{l}\text { Example } \\
\mathbf{2}\end{array}$ & $\begin{array}{l}\text { Example } \\
\mathbf{3}\end{array}$ & $\begin{array}{l}\text { Example } \\
\mathbf{4}\end{array}$ & $\begin{array}{l}\text { Example } \\
\mathbf{5}\end{array}$ \\
\hline 1 & +5 & Fulfills & Fulfills & Fulfills & Fulfills & Fulfills \\
\hline 2 & +5 & $\begin{array}{l}\text { Does not } \\
\text { fulfill }\end{array}$ & Fulfills & Fulfills & Fulfills & Fulfills \\
\hline 3 & +10 & $\begin{array}{l}\text { Does not } \\
\text { fulfill }\end{array}$ & Fulfills & Fulfills & Fulfills & Fulfills \\
\hline 4 & +25 & $\begin{array}{l}\text { Does not } \\
\text { fulfill }\end{array}$ & Fulfills & $\begin{array}{l}\text { Does not } \\
\text { fulfill }\end{array}$ & Fulfills & Fulfills \\
\hline 5 & +30 & Fulfills & $\begin{array}{l}\text { Does not } \\
\text { fulfill }\end{array}$ & Fulfills & Fulfills & Fulfills \\
\hline 6 & +5 & $\begin{array}{l}\text { Does not } \\
\text { fulfill }\end{array}$ & Fulfills & Fulfills & Fulfills & Fulfills \\
\hline 7 & +20 & $\begin{array}{l}\text { Does not } \\
\text { fulfill }\end{array}$ & $\begin{array}{l}\text { Does not } \\
\text { fulfill }\end{array}$ & Fulfills & $\begin{array}{l}\text { Does not } \\
\text { fulfill }\end{array}$ & Fulfills \\
\hline 8 & +5 & Fulfills & Fulfills & $\begin{array}{l}\text { Não Does } \\
\text { not fulfill }\end{array}$ & Fulfills & Fulfills \\
\hline 9 & +15 & $\begin{array}{l}\text { Does not } \\
\text { fulfill }\end{array}$ & Fulfills & Fulfills & Fulfills & Fulfills \\
\hline 10 & +10 & Fulfills & Fulfills & Fulfills & Fulfills & Fulfills \\
\hline Total & 50 points & 80 points & 80 points & $\begin{array}{l}110 \\
\text { points }\end{array}$ & $\begin{array}{l}130 \\
\text { points }\end{array}$ \\
\hline
\end{tabular}

Source: elaborated by the authors (2021).

Therefore, regarding the application of the GDP's visual panel as prescribed by Merino $(2014 ; 2016)$, in the first and second steps information was surveyed and opportunities were prospected (Figure 2); in the third step, the list of attributes by Vieira, Iervolino, and Stadler (2019) was used; in the fourth and fifth steps, the mentioned list was made into a table of project requirements (Table 2); in the sixth and seventh steps, the design tool was tested through five examples found in literature about zero waste (Table 3); and, lastly, in the eighth step it was shown the necessity of using Visual Project Management to potentialize the use of the ZWTAD with stylists and apparel designers. 


\subsection{ZWTAD after the application of Visual Project Management}

Teixeira and Merino (2014) and Teixeira (2018) say that Visual Project Management can gradually subsidize the evolution of a design tool. As an example, the authors present the transformation of a descriptive table as a reference model that, by aggregating new organization topics such as "what is it?", "what to do?", and "how to do it?", becomes a table of steps. Subsequently, to give visibility to the steps and activities being developed by a certain team, graphic representation elements are added to provide a systemic view of the project. Therefore, we have a visual panel that can also unfold into other tools, such as visual timelines, note cards, guidance and exit sheets, among others (Figure 3 ).

Figure 3. Evolution of a reference model under the contribution of Visual Project Management cronograma Visual

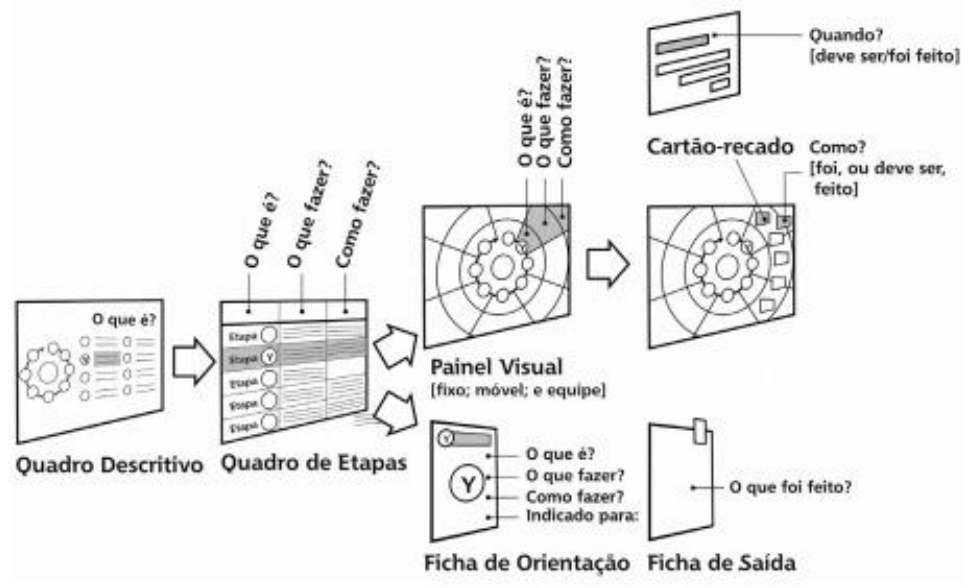

Source: Teixeira and Merino (2014, p. 126).

For Teixeira (2018), the evolution of the reference model (Figure 3) can also happen through the application of a roadmap for visual models. In this perspective, the author presents five fundamental steps: (I) beginning, when you choose a reference model; (II) sprint 1 , when you create a 
table of steps; (III) sprint 2, when you visually improve each table, control, process, and reference model item; (IV) sprint 3 , when the global aspects unfold in detailed parts; and (V) sprint 4, when the way in which the project's information will be stored is defined. The ZWTAD does not follow the roadmap proposed by Teixeira (2018), but it exemplifies the visual evolution illustrated by Teixeira and Merino (2014) by meeting the Visual Project Management structuring elements.

Teixeira (2018) claims that the Visual Project Management structuring elements encompass three aspects: (I) premises; (II) requirements; and (III) usability principles. Regarding the first aspect, the author says that the following premises can be followed when building a visual model: (I) visualization must be prioritized throughout the development process; (II) visual strategies must be applied since the planning of the model; (III) visual maps, infographics, and diagrams must be elaborated to organize action plans; (IV) alternatives to visualize and disseminate information on the investigated model must be created; (V) the visual analysis must be valued; and, lastly, (VI) the interaction and participation of the project team must be promoted and stimulated (Table 4).

Table 4. Application of the Visual Project Management premises in the ZWTAD

\begin{tabular}{|l|l|}
\hline Premise & Changes \\
\hline $\begin{array}{l}\text { 1. Prioritization of the } \\
\text { visualization throughout the } \\
\text { reference model } \\
\text { development process }\end{array}$ & $\begin{array}{l}\text { Colors and icons were added } \\
\text { to the reference model to } \\
\text { distinguish the requirements } \\
\text { of each block, now visually } \\
\text { separated }\end{array}$ \\
\hline $\begin{array}{l}\text { 2. Application of visual } \\
\text { strategies starting from the } \\
\text { planning }\end{array}$ & $\begin{array}{l}\text { The Likert scale was } \\
\text { replaced by the semantic } \\
\text { differential scale by Osgood, } \\
\text { Suci, and Tannenbaum } \\
(1957)^{2}\end{array}$ \\
\hline $\begin{array}{l}\text { 3. Organization of visual } \\
\text { maps, infographics, and } \\
\text { diagrams }\end{array}$ & $\begin{array}{l}\text { The project requirements } \\
\text { were separated in blocks } \\
\text { representing the }\end{array}$ \\
\hline
\end{tabular}




\begin{tabular}{|l|l|}
\hline & $\begin{array}{l}\text { development of garment's } \\
\text { macro steps }\end{array}$ \\
\hline $\begin{array}{l}\text { 4. Creation of alternatives } \\
\text { to visualize and disseminate } \\
\text { information }\end{array}$ & $\begin{array}{l}\text { To match the descriptors, } \\
\text { colors were chosen for } \\
\text { "fulfills", "partially fulfills", } \\
\text { and "does not fulfill" }\end{array}$ \\
\hline $\begin{array}{l}\text { 5. Valuation of visual } \\
\text { analysis }\end{array}$ & $\begin{array}{l}\text { The blocks' graphic elements } \\
\text { got colors to highlight their } \\
\text { characteristics }\end{array}$ \\
\hline $\begin{array}{l}\text { 6. Promotion of interaction } \\
\text { and participation of the } \\
\text { project team }\end{array}$ & $\begin{array}{l}\text { A tool usage guide was } \\
\text { created to help the project } \\
\text { teams }\end{array}$ \\
\hline
\end{tabular}

Source: elaborated by the authors (2021).

With the first changes to the design tool based on the first aspect of the Visual Project Management made, we moved forward to the requirements. For Teixeira (2018), the goal of the requirements is to potentialize the visual model's success and their roles can take on three characters: (I) visual; (II) participatory; and (III) flow. Regarding the visual role, the author says that you should answer the following questions: (I) how to allow the project's global vision on the same plane? (II) how to favor the understanding of and the immediate access to the project's information? and (III) how to facilitate the perception of the relationship between the whole and the parts of the project? Regarding the participatory role, the requirements to be fulfilled are: (I) how to make the project's abnormalities visible? (II) how to ensure the project's flow? and (III) how to stimulate the development of open, simple, easy, and visual processes? Lastly, regarding the flow role, the requirements must be fulfilled through these questions: (I) how to incorporate mechanisms to facilitate guidance, control, and documentation of the project's processes? (II) how to create instruction sheets and standards for what needs to be delivered at each step of the project? and (III) how to support the standardization of the works and the adherence to the processes? (Table 5). 
Table 5. Application of the Visual Project Management requirements in the ZWTAD

\begin{tabular}{|c|c|c|}
\hline Role & Requirement & Changes \\
\hline \multirow[t]{3}{*}{ Visual } & $\begin{array}{l}\text { 1. Disposition of the } \\
\text { project's global vision } \\
\text { on the same plane }\end{array}$ & $\begin{array}{l}\text { The tool's three } \\
\text { blocks were } \\
\text { designed to work as } \\
\text { articulated panels } \\
\text { in the same plane, } \\
\text { if necessary }\end{array}$ \\
\hline & $\begin{array}{l}\text { 2. Understanding of } \\
\text { and immediate access } \\
\text { to the project's } \\
\text { information }\end{array}$ & $\begin{array}{l}\text { The intermediate } \\
\text { descriptors were } \\
\text { arranged in } \\
\text { columns, facilitating } \\
\text { the visual and } \\
\text { immediate } \\
\text { understanding of } \\
\text { the project's } \\
\text { information }\end{array}$ \\
\hline & $\begin{array}{l}\text { 3. Perception of the } \\
\text { relationship between } \\
\text { the whole and the } \\
\text { parts of the project }\end{array}$ & $\begin{array}{l}\text { No changes were } \\
\text { made for this } \\
\text { requirement }\end{array}$ \\
\hline \multirow[t]{3}{*}{ Participatory } & $\begin{array}{l}\text { 4. Visualization of the } \\
\text { project's } \\
\text { abnormalities }\end{array}$ & $\begin{array}{l}\text { A self-filling column } \\
\text { "does not fulfill" } \\
\text { was created }\end{array}$ \\
\hline & $\begin{array}{l}\text { 5. Appointing project } \\
\text { flow }\end{array}$ & $\begin{array}{l}\text { The project flow is } \\
\text { presented through } \\
\text { a logical chain of } \\
\text { the blocks, } \\
\text { sequenced by } A, B \text {, } \\
\text { and } C \text { and by the } \\
\text { requirements' } \\
\text { number, from } 1 \text { to } \\
15\end{array}$ \\
\hline & $\begin{array}{l}\text { 6. Stimulation of the } \\
\text { development of open } \\
\text { processes }\end{array}$ & $\begin{array}{l}\text { No changes were } \\
\text { made for this } \\
\text { requirement }\end{array}$ \\
\hline \multirow[t]{2}{*}{ Flow } & $\begin{array}{l}\text { 7. Incorporation of } \\
\text { mechanisms to } \\
\text { facilitate guidance, } \\
\text { control, and } \\
\text { documentation of the } \\
\text { project's processes }\end{array}$ & $\begin{array}{l}\text { The literature was } \\
\text { reviewed, and five } \\
\text { new requirements } \\
\text { were created, some } \\
\text { unfolding from the } \\
\text { pre-existing } \\
\text { requirements }\end{array}$ \\
\hline & $\begin{array}{l}\text { 8. Creation of } \\
\text { instruction sheets and } \\
\text { standards for what } \\
\text { needs to be delivered } \\
\text { at each step of the } \\
\text { project }\end{array}$ & $\begin{array}{l}\text { Instruction sheets } \\
\text { were created for } \\
\text { each requirement } \\
\text { of the project and, } \\
\text { later, were }\end{array}$ \\
\hline
\end{tabular}




\begin{tabular}{|l|l|l|}
\hline & $\begin{array}{l}\text { incorporated to the } \\
\text { usage guide }\end{array}$ \\
\cline { 2 - 3 } & $\begin{array}{l}\text { 9. Standardization } \\
\text { and adherence to the } \\
\text { processes }\end{array}$ & $\begin{array}{l}\text { The blocks were } \\
\text { standardized to } \\
\text { present the same } \\
\text { layout and the } \\
\text { same number of } \\
\text { requirements }\end{array}$ \\
\hline
\end{tabular}

Source: elaborated by the authors (2021).

After making the changes in the ZWTAD based on the aforementioned requirements (Table 5), an analysis of the third aspect of the Visual Project Management structuring elements was conducted. In this perspective, Teixeira (2018) claims that, to build visual models, the following usability principles must be considered: (I) consistency and coherence; (II) compatibility; (III) user skill; (IV) error prevention and recovery; and (V) visual clarity (Table 6).

Table 6. Application of Visual Project Management usability principles in the ZWTAD

\begin{tabular}{|l|l|}
\hline Usability principle & Changes \\
\hline $\begin{array}{l}\text { 1. Consistency and } \\
\text { coherence }\end{array}$ & $\begin{array}{l}\text { No changes were made for } \\
\text { this principle }\end{array}$ \\
\hline 2. Compatibility & $\begin{array}{l}\text { The technical language of } \\
\text { the tool was reviewed to } \\
\text { agree with the users }\end{array}$ \\
\hline 3. User skill & $\begin{array}{l}\text { Differently from the first } \\
\text { version of the tool, where } \\
\text { the users had to add } \\
\text { points, now the users' topic } \\
\text { reading skills and their } \\
\text { ability to fill in fields are } \\
\text { requested }\end{array}$ \\
\hline $\begin{array}{l}\text { 4. Error prevention and } \\
\text { recovery }\end{array}$ & $\begin{array}{l}\text { No changes were made for } \\
\text { this principle }\end{array}$ \\
\hline 5. Visual clarity & $\begin{array}{l}\text { The tool got colors, icons, } \\
\text { letters, and numbers to } \\
\text { make it more visual to } \\
\text { users }\end{array}$ \\
\hline
\end{tabular}

Source: elaborated by the authors (2021). 
As the Tables 4, 5, and 6 denote, improvement actions were carried out in the tool based on the three aspects of the Visual Project Management structuring elements and on Table 2 as reference models. Premises, requirements, and principles were transformed into twenty attributes (six premises, nine requirements, and five principles). Although not all attributes have been complied to or have generated changes, many of them were modified, with focus on improving the tool's visual performance. Because the tool does not fully comply with the Visual Project Management attributes and with the roadmap steps proposed by Teixeira (2018), we can say that the tool is an incomplete visual model. The results of the changes are illustrated by Figures 4, 5, and 6 .

Figure 4. Block A from the ZWTAD

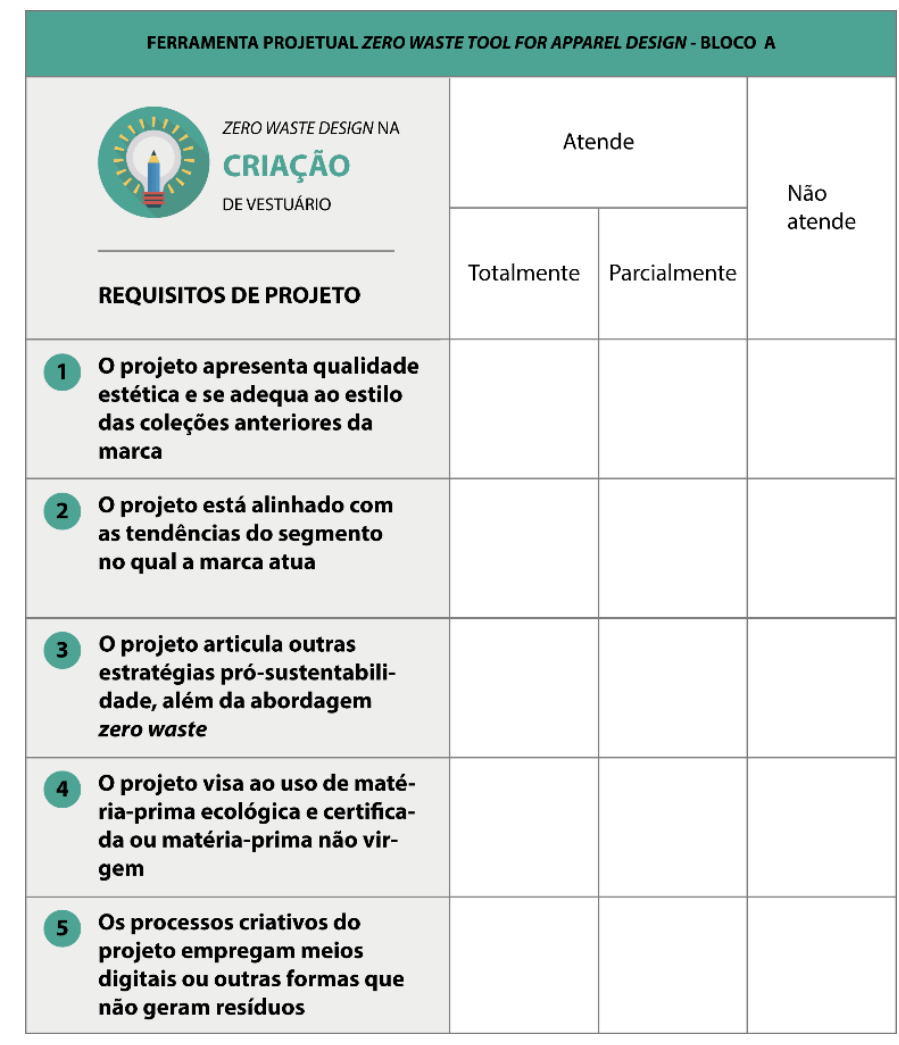

Source: elaborated by the authors (2021). 
The first block of the tool was named Zero Waste Design in clothing creation (Figure 4) and has as project requirements: (I) the project presents aesthetic quality and fits the style of the brand's previous collections; (II) the project is aligned with the trends of the segment in which the brand operates; (III) the project articulates other prosustainability strategies besides the zero waste approach; (IV) the project aims at using ecological and certified raw material or non-virgin raw material; and $(\mathrm{V})$ the project's creative processes use digital media or other media that do not generate waste.

Figure 5. Block B from the ZWTAD

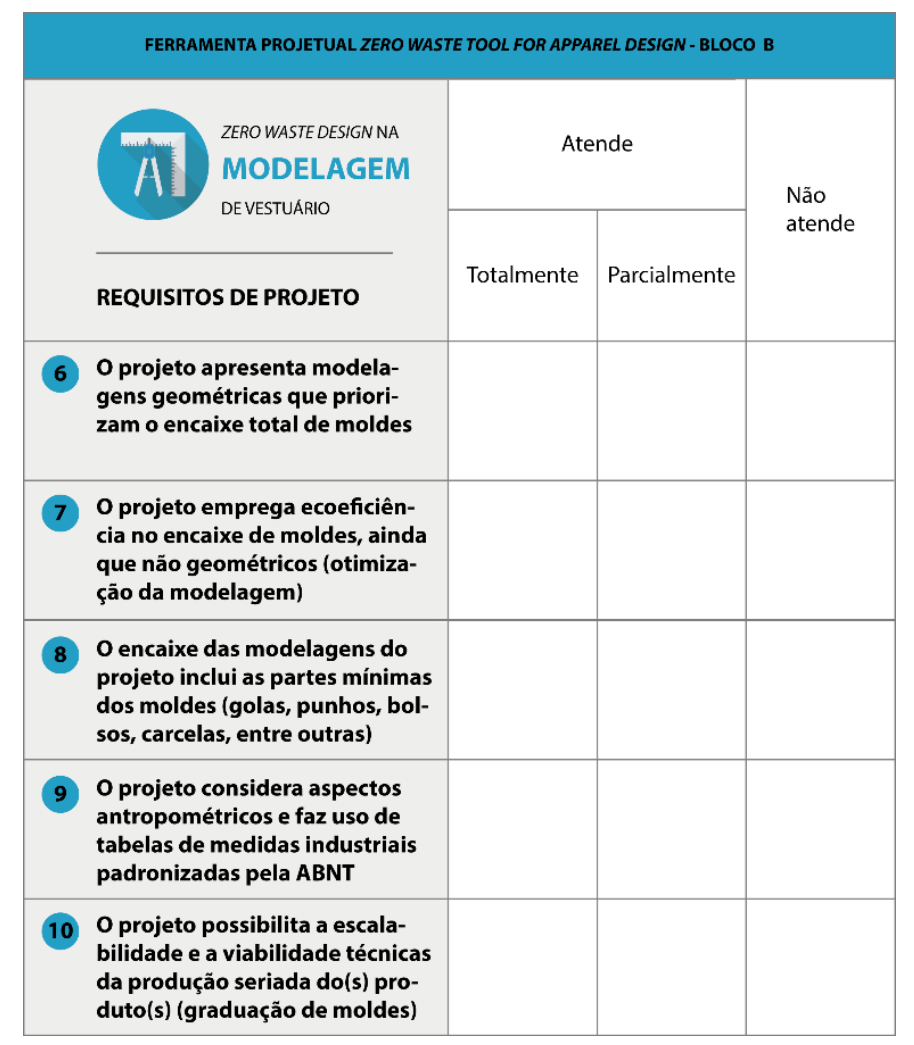

Source: elaborated by the authors (2021)

The second block of the tool, Zero Waste Design in clothing patternmaking (Figure 5), presents as requirements: (I) the project presents geometric patterns that prioritize the 
patterns' perfect fit; (II) the project uses eco-efficiency in pattern fitting, even if not geometric (patternmaking optimization); (III) the fit of the project's patterns include the minimum parts of the patterns (collars, cuffs, pockets, plackets, etc.); (IV) the project considers anthropometric aspects and uses industrial measurement tables standardized by the Associação Brasileira de Normas Técnicas (ABNT); and (V) the project enables scalability and technical viability to allow serial production of the product(s) (adaptation of pattern sizes).

Figure 6. Block C from the ZWTAD

\begin{tabular}{|c|c|c|c|c|}
\hline \multicolumn{5}{|c|}{ FERRAMENTA PROJETUAL ZERO WASTE TOOL FOR APPAREL DESIGN - BLOCO C } \\
\hline \multirow{2}{*}{\multicolumn{2}{|c|}{ REQUISITOS DE PROJETO }} & \multicolumn{2}{|c|}{ Atende } & \multirow{2}{*}{$\begin{array}{l}\text { Não } \\
\text { atende }\end{array}$} \\
\hline & & Totalmente & Parcialmente & \\
\hline 11 & $\begin{array}{l}\text { Os protótipos do projeto foram } \\
\text { gerados por meio digital ou } \\
\text { de outras formas que não } \\
\text { geram resíduos }\end{array}$ & & & \\
\hline 12 & $\begin{array}{l}\text { O projeto apresenta uma } \\
\text { sequência operacional com } \\
\text { número mínimo de operaçöes } \\
\text { possíveis na montagem }\end{array}$ & & & \\
\hline 13 & $\begin{array}{l}\text { O projeto assegura a mitiga- } \\
\text { ção de resíduos em processos } \\
\text { produtivos secundários (pro- } \\
\text { totipagem, testes, entre outros) }\end{array}$ & & & \\
\hline 14 & $\begin{array}{l}\text { O projeto gera apenas o mínimo } \\
\text { resíduo inevitável (aparas, fios } \\
\text { sobressalentes ou ourelas re- } \\
\text { tiradas por segurança) }\end{array}$ & & & \\
\hline 15 & $\begin{array}{l}\text { Caso tenham sido gerados resí- } \\
\text { duos, estes foram reinseridos } \\
\text { no projeto como input para } \\
\text { outros processos }\end{array}$ & & & \\
\hline
\end{tabular}

Source: elaborated by the authors (2021).

The third and last block of the tool, named Zero Waste Design in clothing production (Figure 6), has as project requirements: (I) the project's prototypes were digitally created, or using other mediums that do not generate waste; 
(II) the project presents an operational sequence with a minimum number of possible assembly operations; (III) the project ensures the mitigation of waste in secondary productive processes (prototyping, testing, etc.); (IV) the project produces only inevitable minimum waste (trimmings, spare threads, or selvages removed for safety reasons); and (V) in case of waste production, it is reinserted in the project as input for other processes.

With the results from the application of Visual Project Management (Figures 4, 5, and 6), we proceeded to detail each requirement through a usage guide. The guide is organized in orientation sheets that help the project teams to fill the columns.

After presenting the ZWTAD evolution through Visual Project Management, from its reference model to its final configuration, we proceed to this article's final considerations.

\section{FINAL CONSIDERATIONS}

We believe we have accomplished the goal of this study to show the application of Visual Project Management in the ZWTAD construction. To this end, we used a narrative and unsystematic literature review, leaning towards the design science research method. In this process, the Visual Project Management premises, requirements, and usability principles were transformed into twenty attributes that resulted in changes in the reference model. After the improvement actions, some attributes were not totally complied with and, also, the steps proposed by Teixeira's (2018) roadmap were not followed with precision.

This leads to the conclusion that this article does not present a complete visual model, even if it uses its structuring elements and if it contributes, academically, to the 
development of further discussions in the area by showing the application of Visual Project Management in the evolution of a pro-sustainability design tool.

As research agenda for future studies, we recommend converting Tables 4, 5, and 6 into a single attribute table that can be used in different contexts and projects to verify premises, requirements, and usability principles.

Lastly, we thank the Programa de Pós-Graduação em Design de Vestuário e Moda (PPGModa), from the Centro de Artes (Ceart) of the Universidade do Estado de Santa Catarina (Udesc), as well as the Direção de Pesquisa e Pós-Graduação (DPPG) of the Centro, and the Pró-reitoria de Pesquisa de PósGraduação (PROPPG) of the institution.

\section{End of text notes}

${ }^{1}$ Teixeira (2018) mentions three fundamental questions: (I) how to prioritize the visualization of the project's information? (II) how to promote collective participation? and (III) how to create a continuous flow? The following questions on the paragraph unfold from them.

2 Osgood, Suci, and Tannenbaum's (1957) semantic differential scale refers to the emotional reactions subjects manifest when facing a word, an image, or an object. Opposite descriptors can be placed at both ends of the scale, while intermediate points are chosen to qualify the feelings that emerge from what is being visualized.

\section{REFERENCES}

ANICET, Anne; RÜTHSCHILLING, Evelise Anicet. Contextura: processos produtivos sob abordagem Zero Waste. Modapalavra Eperiódico, Florianópolis, v. 6, n. 11, p.18-36, jul-dez 2013. Disponível em: https://bit.ly/3fchDJj. Acesso em: 05 ago. 2018. 
BINOTTO, Carla; PAYNE, Alice. The Poetics of Waste: Contemporary Fashion Practice in the Context of Wastefulness. Fashion Practice, [s.l.], v. 9, n. 1, p.5-29, 13 out. 2016. Disponível em: https://bit.ly/37K7q4J. Acesso em: 25 jul. 2020.

BONA, Sheila Fernanda. Método de projeto de coleção em design de moda: uma configuração para micro e pequenas empresas. 2019. 136 f. Dissertação (Mestrado) - Curso de PósGraduação em Design de Vestuário e Moda, Universidade do Estado de Santa Catarina, Florianópolis, 2019. Disponível em: https://bit.ly/3plpkAL. Acesso em: 25 jul. 2020.

BREVE, Danilo Gondim. Zero Waste: design sustentável aplicado ao ensino de moda. 2018. 152 f. Dissertação (Mestrado) - Curso de Pós-Graduação em Têxtil e Moda, Escola de Artes, Ciências e Humanidades, Universidade de São Paulo, São Paulo, 2018. Disponível em: https://bit.ly/36J69Jj. Acesso em: 21 fev. 2019.

DRESCH, Aline; LACERDA, Daniel Pacheco; ANTUNES JÚNIOR, José Antônio Valle. Design science research: método de pesquisa para avanço da ciência e tecnologia. Porto Alegre: Bookman, 2015.

DRESCH, Aline; LACERDA, Daniel Pacheco; MIGUEL, Paulo Augusto Cauchick. Uma análise distintiva entre o estudo de caso, a pesquisaação e a design science research. Revista Brasileira de Gestão de Negócios, São Paulo, v. 17, n. 56, p. 1116-1133, 24 nov. 2015. Disponível em: https://bit.ly/3mO2cZQ. Acesso em: 22 dez. 2020.

FIRMO, Francis da Silveira. Zero Waste (Resíduo Zero): uma abordagem sustentável para confecção de vestimentas. In: CONGRESSO BRASILEIRO DE PESQUISA E DESENVOLVIMENTO EM DESIGN, 11., 2014, Gramado. Anais [...]. Gramado: Blucher Design Proceedings, 2014. p. 1-13. Disponível em: https://bit.ly/3rnRvk3. Acesso em: 25 jul. 2020.

GIL, Antônio Carlos. Métodos e técnicas de pesquisa social. 6 . ed. São Paulo: Atlas, 2008.

JHA, Banhi; NARANG, Vandana. Design Research Through Pedagogical Approach to Zero Waste in Apparel. In: INSIGHT 2015: DESIGN RESEARCH SYMPOSIUM, 2015, Bangalore. Anais [...]. Bangalore: National Institute of Design, 2015. p. 1 - 8. Disponível em: http://bit.ly/3axkzzP. Acesso em: 13 jul. 2020.

MERINO, Giselle Schmidt Alves Díaz. GODP - Guia de Orientação para Desenvolvimento de Projetos: uma metodologia de Design Centrado no Usuário. Florianópolis: NGD/UFSC, 2016.

MERINO, Giselle Schmidt Alves Díaz. Metodologia para a prática projetual do Design: com base no projeto centrado no usuário e com ênfase no Design Universal. 2014. 242 f. Tese (Doutorado) Curso de Pós-Graduação em Engenharia de Produção, Universidade Federal de Santa Catarina, Florianópolis, 2014. Disponível em: https://bit.ly/3nKxMsH. Acesso em: 13 jul. 2020.

MERINO, Giselle Schmidt Alves Díaz; VARNIER, Thiago; MAKARA, Elen. Guia de Orientação para o Desenvolvimento de Projetos GODP - aplicado à prática projetual no design de moda. ModaPalavra e-periódico, Florianópolis, v. 13, n. 28, p. 8-47, 
abr.-jun. 2020. Disponível em: https://bit.ly/37JypwY. Acesso em: 13 jul. 2020.

OSGOOD, Charles Egerton; SUCI, George J.; TANNENBAUM, Percy $\mathrm{H}$. The measurement of meaning. Urbana: University of Illinois Press, 1957.

RISSANEN, Timo. Zero-Waste Fashion Design: a study at the intersection of cloth, fashion design and pattern cutting. 2013. 313 f. Tese (Doutorado) - Curso de Pós-Graduação em Filosofia do Design, University of Technology, Sydney, 2013. Disponível em: https://bit.ly/3nAHMo1. Acesso em: 09 dez. 2019.

RIZZI, Suelen. Metodologias de desenvolvimento de produtos de vestuário: abordagem sustentável integrada com a modelagem zero waste. 2018. 208 f. Dissertação (Mestrado) - Curso de PósGraduação em Design, Centro Universitário Ritter dos Reis, Porto Alegre, 2018. Disponível em: https://bit.ly/32UhNQx. Acesso em: 21 ago. 2019.

ROSA, Lucas da. Vestuário Industrializado: uso da ergonomia nas fases de gerência de produto, criação, modelagem e prototipagem. 2011. 175 f. Tese (Doutorado) - Curso de PósGraduação em Design, Departamento de Artes e Design, Pontifícia Universidade Católica, Rio de Janeiro, 2011. Disponível em: https://bit.ly/3kDNtzL. Acesso em: 24 fev. 2019.

TEIXEIRA, Júlio Monteiro. Gestão visual de projetos: utilizando a informação para inovar. Rio de Janeiro: Alta Books, 2018.

TEIXEIRA, Júlio Monteiro; MERINO, Eugenio. Gestão visual de projetos: um modelo voltado para a prática projetual. Strategic Design Research Journal, [s.I.], v. 7, n. 3, p.123-132, 8 jul. 2014. Disponível em: https://bit.ly/3fcDwYN. Acesso em: 20 abr. 2020.

TREPTOW, Doris. Inventando moda: planejamento de coleção. 4. ed. Brusque: Ed. do Autor, 2007.

VIEIRA, Milton Luiz Horn; IERVOLINO, Fernanda; STADLER, Thaís Espezin. Design zero waste para a produção sustentável de uma calça legging. In: ENSUS - ENCONTRO DE SUSTENTABILIDADE EM PROJETO, 7., 2019, Florianópolis. Anais [...]. Florianópolis: Virtuahab/UFSC, 2019. v. 5, p. 509-522. Disponível em: https://bit.ly/38UCFuL. Acesso em: 02 jul. 2019. 